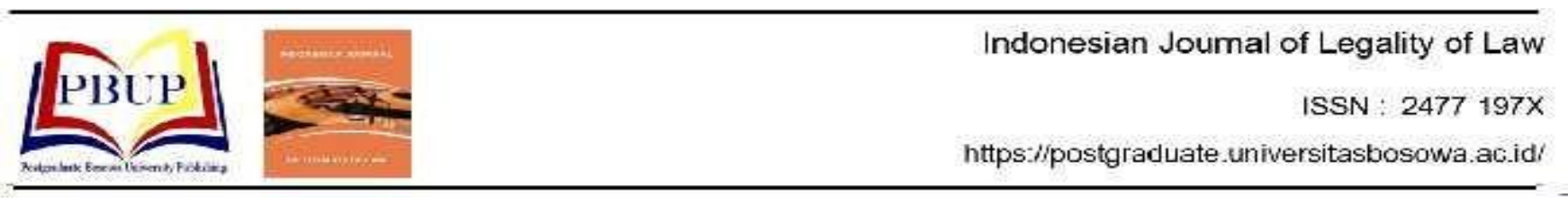

\title{
EFEKTIVITAS PERLINDUNGAN ANAK YANG MELAKUKAN PENCURIAN DENGAN KEKERASAN DI KOTA MAKASSAR (STUDI KASUS PADA POLRESTABES MAKASSAR)
}

\author{
The Effectiveness of Children's Protection Taking Aftingviolence in Makassar City \\ (Case Study on Makassar Polrestabes) \\ Asep Widianto ${ }^{1}$, Marwan $\mathrm{Mas}^{2}$, Yulia A.Hasan ${ }^{2}$ \\ ${ }^{1}$ Mahasiswa Program Studi Ilmu Hukum Program Pascasarjana Universitas Bosowa \\ ${ }^{2}$ Prodi Ilmu Hukum Universitas Bosowa \\ Email: asepwidianto043@gmail.com
}

Diterima: 08 Agustus 2019/Disetujui: 09 Desember 2019

\begin{abstract}
ABSTRAK
Penelitian ini bertujuan untuk mengetahui upaya perlindunganhak asasi anak yang melakukan pencurian dengan kekerasan dalam proses penyidikan di Kota Makassar serta faktor yang meyebabkan terjadinya pencurian dengan kekerasan yang dilakukan oleh anak di Kota Makassar.Penelitian ini dilakukan di Kantor Kepolisian Resort Kota Besar Makassar. Metode yang penulis gunakan adalah penelitian kuantitatif dengan tujuan untuk menguji upaya perlindunganhak asasi anak yang melakukan pencurian dengan kekerasan dalam proses penyidikan di Kota Makassar serta faktor yang meyebabkan terjadinya pencurian dengan kekerasan yang dilakukan oleh anak di Kota Makassar. Hasil penelitian ini menunjukkan bahwa upaya perlindungan hak asasi anak yang melakukan pencurian dengan kekerasan dalam proses penyidikan di Kota Makassarbelum terlaksana sepenuhnya secara baik. Adapaun faktor-faktor yang menyebabkan terjadinya pencurian dengan kekerasan di Kota Makassar adalah faktor kurangnya perhatian orang tua, faktor ekonomi, faktor lingkungan Sosial dan faktor rendahnya pendidikan
\end{abstract}

Kata Kunci: Perlindungan Anak, Pencurian, Kekerasan.

\begin{abstract}
This research aims to know the efforts of protection of the rights of children who commit theft with violence in the process of investigation in the city of Makassar and meyebabkan factors of occurrence of theft with violence committed by children in the city Makassar. This research was conducted at the Office Police Resort great city of Makassar. The authors use the method is quantitative research with the aim to test the protection of the rights of children who commit theft with violence in the process of investigation in the city of Makassar and meyebabkan factors of occurrence of theft with violence committed by children in the city of Makassar. The results of this research show that the protective measures of the rights of children who commit theft with violence in the process of investigation in the city of Makassar has not been done completely well. Adapaun the factors that cause the occurrence of theft with violence in the city of Makassar was a factor in the lack of attention of parents, economic factors, environmental factors and social factors of low education.
\end{abstract}

Keywords: Child Protection, Theft, Violence

\section{PENDAHULUAN}

Anak merupakan aset yang sangat berharga bagi semua negara dan keluarga. Karena anaklah yang akan melanjutkan perjuangan dan kepemimpinan pada sebuah negara. Dengan demikian, keberadaan anak haruslah mendapatkan perhatian yang serius dari negara. Agar anak dapat tumbuh dan berkembang sehingga kelak akan menjadi penerus cita-cita bangsa dan mengisi pembangu-nan Negara (Mardin, 2008).

Begitu pentingnya keberadaan anak dalam sebuah negara, termasuk di Indonesia, maka anak tersebut harus dilindungi oleh negara. Perlindungan terhadap anak tersebut disebutkan dalam Undang-Undang Dasar Negara Re-publik Indonesia Tahun 1945, tepatnya pada Pasal 28B ayat (2) yang menyatakan secara eksplisit bahwa "setiap anak berhak atas kelangsungan hidup, tumbuh dan berkembang serta berhak atas perlindungan dari kekerasan dan diskrimi-nasi. Dari bunyi ayat tersebut dapat dipahami bahwa perlin-dungan bagi anak demi tumbuh kembangnya merupakan kewajiban bagi Negara (Muladi dan Nawawi, 2000; Nan-dang, 2010).

Namun, dewasa ini, seringkali anak mendapatkan hukuman karena kesalahannya yang diakibatkan oleh pola 
asuh yang salah dan perkembangan yang tidak mendidik bagi anak. Sehingga berdampak buruk bagi kelangsungan perkembangan pengetahuan positif bagi anak yang menjerumuskan dan menyeret mereka dalam sebuah perbuatan yang mestinya tidak dilakukan oleh anak akibat salah dalam menyikapi perkembangan teknologi yang semakin mutahir dan canggih dewasa ini (Rena, 2010;Nasir, 2013).

Perlindungan anak dalam Pasal 1 butir 2 UndangUndang Nomor 35 Tahun 2014 tentang Perlindungan Anak (UU Perlindungan Anak) disebutkan bahwa perlindungan anak adalah segala kegiatan untuk menjamin dan melindungi anak dan hak-haknya agar dapat hidup, tumbuh, berkembang dan berpartisipasi, secara optimal sesuai dengan harkat dan martabat kemanusiaan serta mendapat perlindungan dari kekerasan dan diskriminasi.

Dari bunyi pasal tersebut di atas menunjukkan pentingnya perlindungan kepada anak agar dapat tumbuh dan berkembang sehingga dapat melanjutkan pembangunan sebuah negara. Perlindungan terhadap anak ini penting agar hak-haknya dapat terlindungi. Hak tersebut adalah agar dapat hidup, tumbuh, berkembang, dan berpartisipasi secara optimal sesuai dengan harkat dan martabat kemanusian, serta mendapat perlindungandari kekerasan dan diskriminasi (Suharto, 2004; syaiful, 2010).

Undang-undang Nomor 11 tahun 2012 tentang Sistem Peradilan Pidana Anak (UU SPPA) menyebutkan bahwa ada beberapa bentuk perlindungan yang dapat diberikan kepada anak yang melakukan perbuatan pidana, di antaranya pendampingan, bantuan hukum dan diversi. Pendampingan disebutkan dalam Pasal Pasal 3 huruf j UU SPPA yang berbunyi bahwa setiap anak dalam proses peradilan berhak: disebutkan pada huruf $\mathrm{j}$ "memperoleh pendampingan orang tua/wali dan orang yang dipercaya oleh anak." Bantuan hukum disebutkan pada Pasal 23 ayat (1) UU SPPA yang berbunyi bahwa "dalam setiap tingkat pemeriksaan, anak wajib diberikan bantuan hukum dan didampingi oleh pembimbing kemasyarakatan atau pendamping lain sesuai dengan ketentuan peraturan perundang-undangan." Sedangkan diversi disebutkan pada Pasal 7 ayat (1) yang berbunyi bahwa pada tingkat penyidikan, penuntutan, dan pemeriksaan anak di Pengadilan negeri wajib diupayakan diversi (Teguh, 2010; Syamsuddin, 2010; 2014). Jadi diversi harus diuapayakan pada setiap tahap proses hukum yang dialami anak. Pengertian diversi menurut Pasal 1 angka 7 UU SPPAbahwa diversi adalah pengalihan penyelesaian perkara Anak dari proses peradilan pidana ke proses di luar peradilan pidana. Adapun tujuan diversi menurut Pasal 6 UU SPPA bahwa diversi bertujuan:

a. Mencapai perdamaian antara korban dan Anak;

b. Menyelesaikan perkara Anak di luar proses peradilan;

c. Menghindarkan Anak dari perampasan kemerdekaan;

d. Mendorong masyarakat untuk berpartisipasi; dan

e. Menanamkan rasa tanggung jawab kepada Anak.

\section{METODE}

Penelitian ini adalah penelitian empiris yaitu penelitian yang mengkaji tentang penomena hukum yang berhubungan dengan perlindungan terhadap anak yang melakukan pencurian dengan kekerasan. Disamping itu penelitian empiris tersebut dengan menggunakan pendekatan hukum (yuridis) agar sesuai peraturan perundang-undangan yang berhubungan dengan proses perlindungan hukum terhadap anak dalam sistem peradilan pidana anak.

Ada dua jenis data yang dibutuhkan dalam penelitian ini yaitu: data primer dan data sekunder. Data primer adalah data yang diperoleh secara langsung dari hasil wawancara dengan pihak yang terkait yang telah ditetapkan. Sedangkan data se-kunder adalah data yang diperoleh dari penelusuran bahan pustaka berupa buku literatur, artikel ilmiah, hasil penelitian, kumpulan karangan yang relevan dengan penelitian ini serta dokumen-dokumen yang ada pada tempat penelitian yang te-lah ditentukan (Yahya, 2007;2009;).

Pengumpulan data dilakukan dengan cara melakukan wawancara (interview) dengan pihak-pihak yang terkait dengan perlindungan anak yang melakukan pencurian dengan kekerasan yang dilakukan oleh anak di Kota Makassar, dalam hal ini penyidik anak dan anak yang melakukan pencurian dengan kekerasan di Kota Makassar

\section{HASIL DAN PEMBAHASAN}

1. Upaya Perlindungan Hak Asasi Anak yang Melaku-kan Pencurian dengan Kekerasan Dalam Proses Penyidikan di Polrestabes Masakassar

Kejahatan yang saat ini marak terjadi di Kota Makassar adalah pencurian dengan kekerasan yang disingkat curas dan sering pula disebut dengan begal. Sebagai bentuk kejahatan, pencurian dengan kekerasan (curas) atau begal harus men-dapatkan penangan yang serius agar kejatan ini dapat dice-gah. Curas ini bisa dilakukan oleh orang dewasa maupun anak di bawah umur. Pencurian dengan kekerasan yang yang ditangani Kepolisian Resort Kota Besar Makassar cukup banyak setiap tahunnya. Untuk mengetahui jumlah kejatan curas di Kota Makassar 3 (tiga) tahun terakhir dapat dilihat pada tabel berikut ini.

Tabel 1.

Rekap Data Tahunan Jumlah Tersangka Perkara Pencurian Dengan Kekerasan

\begin{tabular}{clccc}
\hline \multirow{2}{*}{ No. } & Bulan & $\begin{array}{c}\text { Tahun } \\
2017\end{array}$ & $\begin{array}{c}\text { Tahun } \\
2018\end{array}$ & $\begin{array}{c}\text { Tahun } \\
2019\end{array}$ \\
\hline 1 & Januari & 53 & 22 & 39 \\
2 & Februari & 63 & 32 & 33 \\
3 & Maret & 47 & 24 & 56 \\
4 & April & 53 & 29 & 14 \\
5 & Mei & 23 & 30 & 16 \\
6 & Juni & 27 & 62 & 23 \\
7 & Juli & 35 & 42 & 34 \\
8 & Agustus & 34 & 36 & - \\
9 & September & 33 & 54 & - \\
10 & Oktober & 31 & 38 & - \\
11 & November & 30 & 38 & - \\
12 & Desember & 28 & 48 & - \\
\hline & Jumlah & 457 & 455 & 215 \\
\hline
\end{tabular}

Sumber: Data Polrestabes Makassar Tahun 2019

Berdasarkan data Tabel 1 tersebut dapat dijelaskan bah-wa Curas yang ada di Kota Makassar yang ditangani Pol-restabes Makassar cukup banyak setiap tahunnya. Tahun 2017 ada 457 kasus, tahun 2018 ada 455 kasus dan sampai pada bulan Juli 2019 sudah ada 215 kasus. Dari data tersebut kemudian diketahui bahwa diantara sekian banyak curas yang ditangani oleh Polrestabes Makassar, ada pula yang dilakukan oleh anak di bawah umur. 
Seperti yang disampaikan oleh Aipda Idham selaku penyidik anak di Polsek Panakkuakng (wawancara pada 19 Agustus 2019) bahwa: Cukup banyak kasus pencurian dengan kekerasan yang kami tangani setiap tahunnya. Kejahatan tersebut bisa dilakukan oleh orang dewasa maupu anak di bawah umur. Meski dilakukan oleh orang dewasa dan anak, kami tidak memisahkan datanya. Baru pada tahun 2018 kami mulai pisahkan data rekap kejatan yang dilakukan oleh orang dewasa dan anak. Untuk mengetahui jumlah Curas atau begal yang dilakukan oleh anak yang ditangani oleh Kepolisian Resort Kota Besar Makassar dapat dilihat pada Tabel 2.

Tabel 2

Rekap Data Tahunan Jumlah Tersangka Anak Perkara Pencurian Dengan Kekerasan

\begin{tabular}{clcc}
\hline No. & \multicolumn{1}{c}{ Bulan } & Tahun 2018 & Tahun 2019 \\
\hline 1 & Januari & 9 & 12 \\
2 & Februari & 15 & 18 \\
3 & Maret & 10 & 26 \\
4 & April & 12 & 9 \\
5 & Mei & 18 & 7 \\
6 & Juni & 44 & 6 \\
7 & Juli & 28 & 8 \\
8 & Agustus & 19 & - \\
9 & September & 30 & - \\
10 & Oktober & 12 & - \\
11 & November & 16 & - \\
12 & Desember & 21 & - \\
\hline Jumlah & & 234 & 86 \\
\hline Sumber & Data Polrestbes Makassar Tah &
\end{tabular}

Sumber: Data Polrestabes Makassar Tahun 2019

Berdasarkan data pada Tabel 2 menunjukkan bahwa curas atau begal yang dilakukan oleh anak yang ditangani Polrestabes Makassar pada tahun 2018 cukup banyak, yakni sebesar 234 kasus dan sampai pada bulan Juli 2019 sudah ada 86 kasus. Kasus ini akan terus bertambah, apalagi kalau sampai tidak ditangani secara serius, dan akan menjadi masalah yang sangat berbahaya mengingat hal tersebut dilakukan oleh anak yang merupakan aset bangsa. Olehnya itu, Kepolisian Resort Kota Besar Maka-ssar sebagai institusi negara yang bertugas untuk meme-lihara keamanan dan ketertiban masyarakat, menegakkan hukum, serta memberikan perlindungan, pengayoman dan pelayanan kepada masyarakat. Dengan demikian maka, kasus Curas atau Begal ini harus mendapatkan perhatian yang serius dari Polrestabes Makassar.

Adapun upaya yang dilakukan penyidik seperti yang disampaikan oleh Aipda Idham selaku penyidik (wawancara, 19 Agustus 2019) bahwa: Tetap kami lakukan penyidikan nanun tetap bekerjasama dengan pihak Bapas yang melakukan penelitian yang nantinya disertai dengan hasil Litmas dan dilampirkan di BAP, dan juga memberikan penasehat hukum dengan cara meminta dan menyurat ke Pusbakum untuk pendampingan di persidangan peradilan anak. Kami tidak akan melakukan penahanan terhadap tersangka yang merupakan anak.

Dari penjelsan penyidik tersebut, dapat diketahui bahwa, anak yang melakukan pencurian dengan kekerasan tetap dilakukan penyidikan meski pihak penyidik tetap bekerjasama dengan Balai Pemasyarakatan (Bapas) yang melakukan penelitian kemasyarakatan (Litmas) dan dilam- pirkan dalam berita acara pemeriksaan (BAP) dan anak diberikan pendampingan hukum.

\section{a. Pendampingan}

Anak yang melakukan pelanggaran pidana berhak men-dapatkan pendampingan. Hal itu disebutkan dalam Pasal 3 huruf j Undang-Undang Nomor 11 Tahun 2012 Tentang Sis-tem Peradilan Pidana Anak (UU SPPA) yang berbunyi bah-wa setiap anak dalam proses peradilan berhak: disebutkan pada huruf $j$ "memperoleh pendampingan orang tua/wali dan orang yang dipercaya oleh anak."

Menurut Analiansyah dan Syarifah bahwa UU SPPA mengatur adanya keterlibatan pendamping Anak yang berha-dapan dengan hukum. Pendamping tersebut adalah:

a. Pembimbing kemasyarakatan, yaitu pembimbing kema-syarakatan adalah pejabat fungsional penegak hukum yang melaksanakan penelitian kemasyarakatan, pembim-bingan, pengawasan, dan pendampingan terhadap anak di dalam maupun di luar pengadilan pidana

b. Pekerja sosial profesional adalah seseorang yang bekerja, baik di lembaga pemerintah maupun swasta, yang memiliki kompetensi dan profesi pekerjaan sosial serta kepedulian dalam pekerjaan sosial yang diperoleh melali pendidikan, pelatihan dan/atau pengalaman praktik pe-kerjaan sosial untuk melaksanakan tugas pelayanan dan penanganan masalah sosial anak.

c. Tenaga kesejahteraan sosial adalah seseorang yang dididik dan dilatih secara profesional untuk melaksanakan tugas pelayanan dan penanganan masalah sosial dan/atau seseorang yang bekerja, baik di lembaga peme-rintah maupun swasta, yang ruang lingkup kegiatannya di bidang kesejahteraan sosial anak.

d. Keluarga adalah orang tua yang terdiri atas ayah, ibu dan/atau anggota keluarga lainnya yang dipercaya oleh anak.

e. Wali adalah orang atau badan yang dalam kenyataannya menjalankan kekuasaan asuh sebagai orang tua terhadap anak.

f. Pendamping adalah orang yang dipercaya oleh anak untuk mendampinginya selama proses peradilan pidana berlangsung.

g. Advokat atau pemberi bantuan hukum lainnya adalah orang yang berprofesi memberi jasa hukum, baik di dalam maupun di luar pengadilan yang memenuhi persyaratan berdasarkan ketentuan peraturan perundangundangan.

h. Lembaga Pembinaan Khusus Anak yang selanjutnya disingkat LPKA adalah lembaga atau tempat anak menjalani masa pidananya.

i. Lembaga Penempatan Anak Sementara yang selanjutnya disingkat LPAS adalah tempat sementara bagi anak selama proses peradilan berlangsung.

j. Lembaga Penyelenggara Kesejahteraan Sosial yang selanjutnya disingkat LPKS adalah lembaga atau tempat pelayanan sosial yang melaksanakan penyelenggaraan kesejahteraan sosial bagi anak.

k. Klien Anak adalah anak yang berada di dalam pelayanan, pembimbingan, pengawasan dan pendampingan pembimbingan kemasyarakatan. 
1. Balai Pemasyarakatan yang selanjutnya disebu Bapas adalah unit pelaksana teknis pemasyarakatan yang melaksanakan tugas dan fungsi penelitian kemasyarakatan, pembimbingan, pengawasan dan pendampingan.

Pendampingan bagi anak yang melakukan perbuatan pidana pada tahap penyididkan bertujuan agar dapat terwujud proses penyidikan yang benar-benar menjamin perlindungan kepentingan terbaik terhadap anak yang berhadapan dengan hukum. Pendampingan terhadap anak yang melakukan pencurian dengan kekerasan di Kota Makassar didampingi oleh orang tua/Wali, orang yang dipercaya oleh anak, atau pekerja sosial. Akan tetapi, jika orang tua dari anak tersebut adalah pelaku tindak pidana, maka orang tua/Walinya tidak wajib mendampingi (Pasal 23 Ayat (3) UU SPPA).

Menurut Idham yang merupakan penyidik anak (wawancara, 22 Agustus 2019) bahwa Anak yang melakukan pencurian dengan kekerasan yang tanganinya semua di dampingi oleh orang tuanya atau walinya serta pekerja sosial. Karena anak di bawah umur jangan sampai takut memberikan keterangan dan ingin memastikan bahwa penyidikan berjalan sesuai dengan prosedur. Olehnya itu kehadiran orang tua atau wali atau pekerja sosial penting. Kalau disimak pernyataan penyidik anak tersebut di atas dapat diketahui bahwa hak anak untuk didampingi oleh orangtua/wali atau pekerja sosial telah terpenuhi.

\section{b. Bantuan Hukum}

Undang-Undang Nomor 11 tahun 2012 Tentang Sistem Peradilan Pidana Anak (UU SPPA) mewajibkan anak yang melakukan tindak pidana untuk mendapatkan bantuan hukum tanpa mempermasalahkan jenis tindak pidana yang telah dilakukan. Berdasarkan Pasal 23 ayat (1) UU SPPA disebutkan bahwa "dalam setiap tingkat pemeriksaan, anak wajib diberikan bantuan hukum dan didampingi oleh pembimbing kemasyarakatan atau pendamping lain sesuai dengan ketentuan peraturan perundang-undangan."

Dari bunyi pasal tersebut di atas dapat diketahui bahwa Anak berhak mendapatkan bantuan hukum di setiap tahapan pemeriksaan, baik dalam tahap penyelidikan, penyidikan, penuntutan, maupun tahap pemeriksaan di pengadilan Anak. Adapun mengenai bantuan hukum yang diberikan kepada anak yang melakukan pencurian dengan kekerasan yang dilakukan oleh anak di Kota Makassar, Idhan selaku penyidik anak menjelaskan (Wawancara, 22 Agustus 2019) bahwa: Mendapatkan bantuan hukum bagi anak merupakan keharusan. Makanya kami (penyidik anak) harus menyurat ke Pusat Bantuan Hukum (Pusbakum) untuk meminta penasehat hukum yang sekarang ini kalau di Kota Makassar berkantor di Pengadilan Negeri. Jadi anak yang berurusan dengan hukum akan mendapatkan bantuan hukum.

Dari pernyataan penyidik anak tersebut di atas dapat diketahui bahwa hak anak dakam mendapatkan bantuan hukum sudah terpenuhi karena setiap anak yang melakukan perbuatan pidana diberikan bantuan hukum. Penyidik menyurat ke Pusat Bantuan Hukum untuk meminta agar lembaga tersebut memberikan bantuan hukum kepada anak yang melakukan pencurian dengan kekerasan.

\section{c. Diversi}

Diversi disebtkan pada Pasal 7 ayat (1) yang berbunyi bahwa pada tingkat penyidikan, penuntutan, dan pemeriksaan anak di Pengadilan negeri wajib dan perlu diupayakan diversi. Jadi diversi harus diupayakan pada setiap tahap proses hukum yang dialami anak. Berdasarkan Pasal 1 angka 7 UU SPPA bahwa diversi adalah pengalihan penye-lesaian perkara Anak dari proses peradilan pidana ke proses di luar peradilan pidana. Adapun tujuan diversi menurut UU SPPA adalah untuk:

a. Mencapai perdamaian antara korban dan Anak;

b. Menyelesaikan perkara Anak di luar proses peradilan;

c. Menghindarkan Anak dari perampasan kemerdekaan;

d. Mendorong masyarakat untuk berpartisipasi; dan

e. Menanamkan rasa tanggung jawab kepada Anak. Menurut Pasal 29 ayat UU SPPA bahwa

(1) penyidik wajib mengupayakan diversi dalam waktu paling lama tujuh hari setelah peyidikan dimulai

(2) proses diversi sebagaiamana dimaksud pada ayat (1) dilaksanakan paling lama tiga puluh hari setelah dimulainya diversi.

(3) Dalam hal proses diversi berhasil mencapai kesepakatan, penyidik menyampaikan berita acara diversi beserta kesepakatan diversi kepada ketua pengadilan negeri un-tuk dibuat penetapan

(4) Dalam hal diversi gagal, penyidik wajib melanjutkan penyidikan dan melimpahkan perkara ke Penuntut umum dengan melampirkan berita acara diversi dan laporan penelitian kemasyarakat

Mengenai pelaksanaan diversi di Kota Makassar, menurut Aipda Idam selaku penyidik anak (wawancara, 22 Agustus 2019) bahwa: Kalau Menurut saya diversi jarang terjadi, kecuali jika korban punya itikad baik mencabut laporannya dan tidak melanjutkan, biasanya jika barang bukti ada di tangan korban selalu diversi daripada lanjut, prosesnya panjang dan untuk mendapatkan barangnya lagi melalui pro-ses yang panjang pula.

Kalau diperhatian pernyataan Aipda Idham selaku penyidik anak tersebut di atas, dapat diketahui bahwa penyi-dik dalam melakukan penyidikan terhadap anak yang mela-kukan pencurian dengan kekerasan di Kota Makassar tidak menjadikan diversi sebagai sarana penyelesaian konflit per-tama dan utama. Padahal, dalam pandangan penulis harusnya diversi merupakan jalan pertama yang ditempuh apabila ada anak yang berurusan dengan hukum. Sebagaimana dise-butkan pada UU Sistem Peradilan Pidana Anak Pasal 5 ayat (3) bahwa dalam sistem peradilan pidana anak wajib diupa-yakan diversi. Diversi dilakukan melalui musyawarah de-ngan melibatkan anak dan orang tua/walinya, korban dan/ atau orang tua/walinya, pembimbing kemasyarakatan, dan pekerja sosial profesional berdasarkan pendekatan keadilan restoraktif. Apalagi anak yang melakukan perbuatan pidana tersbut bukanlah residivis. Anak melakukan perbuatan pen-curian dengan kekerasan karena belum memiliki penge-tahuan dan pemahaman akan dampak kejahatan yang ia telah lakukan.

\section{Faktor Penyebab Terjadinya Pencurian dengan Ke- kerasan yang Dilakukan oleh Anak di Kota Maka- ssar}

Meningkatnya Angka kejahatan Curas atau begal yang melibatkan anak di bawahumur di wilayah hukum Polres- 
tabes Makassar yang merupakan salah satukasus yang perlu mendapatkan penangan seius. Hal tersebut terbukti dengan kasus yangterjadi selama tahun 2018 diwilayah hukum Polrestabes Makassarsebanyak 234 kasus kejahatan yang dilakukan oleh anak dan sampai pada bulan Juli 2019 sudah 86 kasus. Olehnya itu salah satu yang perlu untuk dilakukan adalah mengetahui faktor penyebab terjadinya pencurian dengan kekerasan yang dilakukan oleh anak di wilayah hukum Polrestabes makassar sehingga nantinya dapat dirumuskan upaya pencegahan sesuai yang tidak meninggalkan uapaya perlindungan anak yang komprehensif.

Adapun faktorpenyebab terjadinya pencurian dengan kekerasan yang dilakukan oleh anak di Kota Makassar yaitu:

\section{a. Faktor Kurangnya perhatian orang tua}

Anak yang tidak mendapatkan perhatian dari orang tua akan mencari sesuatu di luar rumah yang dapat menyenangkan hatinya. Karena di dalam rumah anak merasa bosan karena tidak adanya perhatian dari oarng tua. Akibatnya, anak akan melakukan sesuatu yang bisa membuat dia merugikan orang lain. Seperti mencuri dengan kekerasan. Seperti yang disampaikan oleh Farhan Fauzan Irman Alias Farhan anak yang berusia 15 tahun ini mengaku dirinya melakukan pencurian dengan kekerasan di jalan dengan mencuri tas milik pengendara motor yang melewati jalan raya.

Dalan penjelassnya Farhan mengatakan (wawancara, 19 Agustus 2019) bahwa: Saya bosan di rumah, bapak dan ibu sibuk kerja tidak ada yang mau peduli dengan saya. Ya sudah saya keluar bersama teman di jalan. Saya dan teman mencuri tas yang berisi laptop milik perempuan yang singgah di pinggir jalan. Kami mendekati dan mengancam dengan busur. Lalu dia menyerahkan tasnya. Setelah mengambil kami langsung kabur dan laptop kami jual untuk dipakai beli makanan, minuman, dan rokok untuk kami pakai begadang.

\section{b. Faktor Ekonomi}

Karena faktor ekonomi, anak bisa melakukan pencurian dengan kekerasan. Demi untuk memenuhi kebutuhan ekonomi anak yang serba sulit dapat menyebabkan anak tersebut melakukan perbuatan pencurian dengan kekerasan. Seperti yang disampaikan oleh Renaldy alias Andy anak berumur 15 yang melakukan pencurian dengan kekerasan (wawancara, 19 agustus 2019) bahwa: Saya mencuri motor karena tidak punya uang. Bapak saya telah meninggal dan ibu telah menikah lagi dan saya tidak pernah dikasi uang karena ibu juga tidak punya uang sementara adik saya banyak ada 5 orang. Karena ibu tidak kasi saya uang maka saya tidak punya uang jajan. Maka saya mencuri motor agar bisa saya jual yang uangnya saya pake jajan dan uang sekolah.

Dari hasil wawancara tersebut di atas diketahui bahwa salah satu yang menjadi faktor penyebab terjadinya pencurian dengan kekerasan yang dilakukan oleh anak di Kota makassar adalah faktor ekonomi. Karena demi untuk memenuhi kebutuhannya anak terpaksa mencuri.

\section{c. Faktor Rendahnya Pendidikan}

Masih rendahnya pendidikan anak yang juga berdampak pada lemahnya iman dan takwa pada anak. Dengan lemahnya pendidikan ini juga berdampak pada tidak ada- nya filter bagi anak untuk memilah dan memilih apa yang harus dilakukan.

Seperti yang disampaikan oleh Aipda Idham selaku penyidik (wawancara, 19 Agustus 2019) bahwa: "Rata-rata anak yang melakukan pencurian dengan kekerasan itu adalah anak yang tidak beres pendidikannya. Rata-rata mereka putus sekolah."

Dari penjelasan tersebut di atas dapat dipahami bahwa anak yang tidak beres pendidikannya atau putus sekolah dapat mengakibatkan anak melakukan pencurian dengan ke-kerasan. Hal itu bisa terjadi karena mereka tidak mendapatkan pencerahan tentang kejatan sebagai sesuatu yang tidak boleh dilakukan. Olehnya itu pendidikan yang baik bagi anak sangat penting sebagai upaya pencegahan terhadap ke-jahatana yang akan dilakukan oleh anak dan pendidikan ini penting sebagai uapaya memberikan pemahaman dan penge-tahuan tentang kebaikan kepada anak sebagai bekal dalam mengarungi kehidupan di tengahtengah masyarakat.

\section{d. Faktor Lingkungan Sosial}

Lingkunag dimana anak berada sangat berpengaruh dalam membentuk pola pikir dan tingkah laku. Lingkungan pergaulan anakdengan teman-lemannya yang kurangbaik se-hingga akan berdampak pula dengan pola prilaku yang ku-rang baik pula. Seperti yang disampaikan oleh Farhan (wa-wancara, 19 Agustus 2019) bahwa: pada awalnya saya cuma ikut-ikut karena diajak sama teman-teman karena bosan di rumah tidak ada perhatian dari orang tua. Setelah beberapa kali ikut, akhirnya saya senang juga dan menjadi kebiasan. Jadi kalau tidak ada kegiatan dan bosan di rumah akhirnya kami pergi lagi mabbegal di jalan yang agak gelap dan tidak ramai orang yang lewat.

Dari hasil wawancara tersebut di atas dapat diketahui bahwa anak yang awalnya tidak punya niat melakukan keja-hatan, tapi karena diajak oleh teman-temannya akhirnya ikut pula melakukan kejahatan. Dan yang menyedihkan akhirnya anak tersebut mengangkap perbuatan tersdebut sebagai per-buatan yang biasa karena sudah sering melakukan kejahatan. Olehnya itu, anak harus senangtiasa diarahkan untuk bergaul dengan teman-teman yang baik agar tidak terpengaruh untuk melakukan hal-hal yang dapat merugikan orang lain dan masa depannya.

\section{KESIMPULAN}

Berdasarkan hasil penelitian ini, maka dapat disimpulkan bahwa, upaya perlindungan hak asasi anak yang melakukan pencurian dengan kekerasan dalam proses penyidikan di Kepolisian Resort Kota Besar Makassar sudah dilaksanakan namun, belum sepenuhnya sesuai dengan Undang-Undang Nomor 11 Tahun 2012 Tentang Sistem/Cara Peradilan Pidana Anak. Dari segi pendampingan, Anak telah mendapatkan pendampingan dari orang tua/wali dan pekerja sosial, begitu juga dari segi bantuan hukum. Anak yang melakukan pen-curian dengan kekerasan telah mendapatkan bantuan hukum. Tapi dari segi diversi, belum terpenuhi; dan Faktor penyebab terjadinya pencurian dengan kekerasan yang dilakukan oleh anak di wilayah hukum Kepolisian Resort Kota Besar Ma-kassar antara lain: kurangnya perhatian orang tua, kesu-litan ekonomi, rendahnya pendidikan, dan lingkungan sosial yang tidak mendukung. 


\section{DAFTAR PUSTAKA}

Mardin Gulton. (2008). Perlindungan Hukum terhadap Anak Dalam Sistem Peradilan Pidana Anak di Indonesia. Ban-dung : Ketika Aditama.

Muladi dan Barda N.A. (2000). Perbandingan Hukum Pidana. Bandung : Mandar Maju, Bandung.

Nandang Sambas. (2010). Perubahan Sistem Pemidanaan Anak di Indonesia. Bandung, Graha Ilmu.

Nasir Djamil, M (2013). Anak Bukan Untuk Dihukum, Sinar Grafika, Jakarta

Rena Yulia. (2010). Viktimologi Perlindungan Hukum Terhadap Korban Kejahatan, Rgaha Ilmu, Yogyakarta

Suharto, R.M. (2004). Penuntutan Dalam Praktek Peradilan, Sinar Grafika, Jakarta.

Syaiful Bakhri. (2010). Kebijakan kriminal dalam Perspektif Pembaharuan Sistem Peradilan Pidana Indonesia, Total Media, Jogyakarta

Syamsuddin, P. (2014). Sosiologi dan Sosiologi Hukum suatu pengetahuan Praktis dan Terapan, Makassar, Arus Timur

(2010.) Metodologi Penelitian \& Penulisan Karya Ilmiah Hukum Suatu Pengetahuan Praktis, Makassar, Umithoha.

Syamsuddin, P. (2011). Filsafat \& Filsafat Hukum, Makassar, Umithoha

Teguh Prasetyo. (2010). Kriminalisasi Dalam Hukum Pidana. Bandung: Nusamedia.

Yahya Harahap M. (2009). Pembahasan Permasalahan dan Penerapan KUHAP Penyidikan dan Penuntutan, Jakarta, Sinar Grafika

(2007). Pembahasan Permasalahan dan Penerapan KUHAP Pemeriksaan Sidang Pengadilan, Banding, Ka-sasi dan Peninjauan Kembali, Jakarta, Sinar Grafika 